\title{
The Effect of Snakehead Fish (Channa striata) Extract on Blood Leukocyte Number and Cesarean Sectio Wound Healing
}

\author{
${ }^{1}$ Yuli Suryanti, ${ }^{2}$ Suharyo Hadisaputro, ${ }^{3}$ Sri Achadi Nugraheni \\ \{yulisuryanti21@yahoo.com ${ }^{1}$, prof haryo@yahoo.co.id ${ }^{2}$, s.a.nugraheni.undip@gmail.com ${ }^{3}$ \} \\ ${ }^{1,2,3}$ Postgraduate Masters in Applied Midwifery; Health Ministry Polytechnic of Semarang, \\ Indonesia
}

\begin{abstract}
Postoperative hematological change was characterized by leukocytosis in the inflammatory phase due to lack of blood fluids. The study aimed to explain the effect of snakehead fish extract on blood leukocyte number and wound healing for postoperative caesarean sectio patients. The research method used was True-experiment Design. The instrument to measure the number of leukocytes was Hematology Analyzer Method while wound healing used REEDA Scale. The data gathering was carried out on the 3rd, 5 th and 8th days. The results showed that snakehead fish extract giving had an effect on blood leukocytes number with p-value of 0.003 . The average wound healing occurred on the 8th day with p-value of 0.001 . Based on the above results it could be concluded that snakehead fish extract giving of $700 \mathrm{mg} 2 \times 1$ for 7 days to postoperative caesarian sectio patients had an effect to the blood leukocytes number and wound healing.
\end{abstract}

Keywords: Blood Leukocyte Number, Snakehead Fish Extract And Wound Healing

\section{Introduction}

Wound healing process is divided into 3 phases, namely inflammatory phase, proliferation phase and remodeling phase [1] and is influenced by several factors, among others, nutrition, obesity, anemia, personal hygiene, smoking, co-morbidities, stress and vascularization [2].

The World Health Organization (WHO) said that the incidence of caesarean sectio increased 5 times from the previous year that was in the range of 5-15\% per 1000 births in the world [3]. The countries having the highest incidence of caesarean sectio were Brazil (52\%), Cyprus (51\%) and Mexico (39\%). Based on the Indonesian Health Demographic Survey (SDKI) in 2017 the number of national caesarean sectio delivery was recorded at $17 \%$ of the total delivery number [4]. Out of the pecentage the number of caesarean sectio deliveries conducted at government hospitals was $30-35 \%$ of the total deliveries meanwhile it was higher at private hospitals, around 30-80\% [4]. Central Java, one of the most populated provinces in Indonesia, had caesarean sectio deliveries $15.9 \%$ of 2,034 total deliveries and 124 of them were conducted at Ungaran Regional Hospital.

Caesarean sectio is one of the artificial delivery methods by surgery on the part of abdominal wall and uterus to give birth to the baby. Complications that possibly occur in a caesarean sectio delivery include organ damages such as urinary vesica, anesthetic complications, thrombi-embolism, bleeding and infection. The infection causes are among others arthritis, pelvic inflammation, thrombi-phlebitis and delivery injuries [5]. 
Signs and symptoms of an inflammatory reaction could be in the form of redness due to dilation (rubor), pain (dolor) and swelling (tumor). Leukocyte movement occurs because of the cellular activity penetrating the blood vessel wall (diapedesis) to the wound [6]. After the surgery there is hematologic changes in inflammatory phase that is increasing leukocytes and the increase goes to peak at the level of $14,000-16,000 / \mu 1$. Increased number of leukocytes will risk infection if external factors are not well controlled as nutritional intake [7].

One of the ways to control the leukocytes number in order the infection will not occur is by consuming nutrients containing high protein. Snakehead fish can be used as an anti-inflammatory and it will accelerate the process of wound healing [6]. Snakehead fish contains unsaturated fatty acids which function as anti-inflammatory and to regulate prostaglandin synthesis acting as a blood vessel vasodilator. It, thereby, will regulate neutrophil infiltration and activation in the inflammatory process and induces wound healing [8].

Based on the description above the objective of this study is to explain the effects of snakehead fish extract to blood leukocyte number and wound healing of the patients having caesarean sectio surgery at Ungaran Hospital. The novelty of this study was the measurement on blood leukocyte number. Whereas, the previous study measured albumin serum levels and $\mathrm{Hb}$ post sectio caesarea. It was expected that the patients did not abstain to eat high protein food. Moreover, snakehead fish as additional protein intake that could alsobe used as an alternative way to accelerate wound healing process.

\section{Method}

2.1 Sampel and Sampling Technique

This study was conducted at Ungaran Hospital and the samples were 26 postpartum mothers who were divided into 2 groups 13 mothers belonged to intervened group (getting snakehead fish extract) and the rest 13 belonged to control group (getting standard therapy). The sampling technique was randomized, particularly simple random sampling.

2.2 Research Design

This study used true-experiment design with post-test only control group design.

2.3 Data Collection

Data Collection on primary data and secondary data

2.4 Data Analysis

The data analysis of this study applied repeated measure ANOVA (between-subject test) and independent t-test.

\section{Results and Discussion}

A. Analysis of the effects of snakehead fish extract to leukocyte number

Table 1 Measurement of the blood leukocyte numbers to the intervened and control groups.

\begin{tabular}{ccccccc}
\hline Variable & \multicolumn{5}{c}{ Category } & \multirow{2}{*}{ P-value } \\
& \multicolumn{2}{c}{ Intervened } & \multicolumn{2}{c}{ Control } & \\
\cline { 1 - 4 } Leukocyte & $\mathrm{N}$ & $\%$ & $\mathrm{~N}$ & $\%$ & 0.003 \\
Normal & 11 & 40.7 & 7 & 25.9 & \\
High & 2 & 7.4 & 6 & 22.2 & \\
Mean \pm SD & $8.4731 \pm 2.006$ & $11.7269 \pm 2.828$ & \\
\hline
\end{tabular}


The table above showed that the intervened group had normal leukocyte number $40.7 \%$ and high leukocytes number $7.4 \%$. Meanwhile, the normal leukocyte number of the control group was $25.9 \%$ and the high leukocytes number was $22.2 \%$. The result above indicated that snakehead fish extract had an effect to the blood leukocytes number with a value of $p=0.003$.

Leukocytes are white blood cells functioning as immune system defenses to get rid of foreign objects that cause infection. Infection is characterized by an increase of leukocytes number (leukocytosis) or a decrease of leukocytes number (leukopenia). There are 5 (five) types of leukocytes, namely neutrophils, eosinophils, basophils, monocytes and lymphocytes. The most numerous types of leukocytes are neutrophils around $50-70 \%$ which function as the body's defence lines against bacteria and foreign bodies that are phagocyte.

A study conducted by Jumriani showed that an increasing number of leukocytes occurred in early ruptured membranes. In this case KPD would possibly increase the number of leukocytes by 2.6 times due to the rupture of the membranes so that microorganisms entered the vagina and caused inflammation. [9]. Another study conducted by Karminingtyas showed that cesarean surgery patients suffering from leukocytosis were $58.62 \%$ [10]. The factor affecting high leukocytes at the inflammatory phase was lack of fluid due to surgery such as loss of blood fluid [7].

B. Analysis of the effect of snakehead fish extract to would healing post caesarean sectio surgery

Table 2. Effect of snakehead fish extract to wound healing

\begin{tabular}{cccccc}
\hline Source & $\begin{array}{c}\text { Type III } \\
\text { sum of } \\
\text { squares }\end{array}$ & df & $\begin{array}{c}\text { Mean } \\
\text { square }\end{array}$ & $f$ & Sig \\
\hline Wound & 782.167 & 1 & 782.167 & 2011.286 & 0.001 \\
\hline
\end{tabular}

The table above showed that snakehead fish extract had an effect to wound healing as $p$ value $=$ 0.001 .

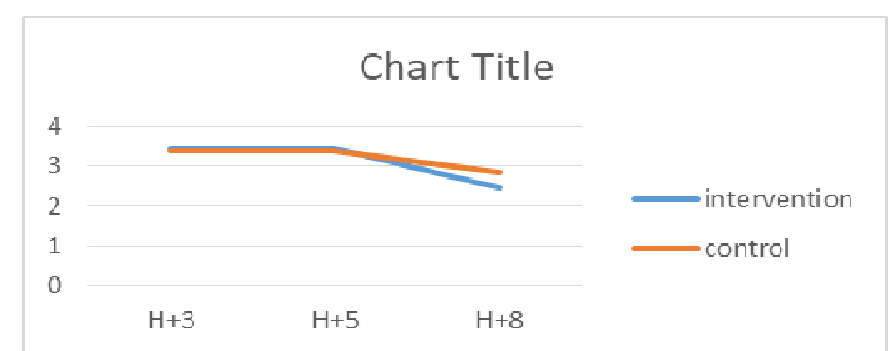

Figure 1.1 Average difference of wound healing between intervened and control groups

The giving of snakehead fish extract as much as $700 \mathrm{mg} 2 \times 1$ for 7 days statistically showed that there was an effect of such a giving to wound healing of the postoperative caesarean sectio patients. The difference of the snakehead fish extract giving to the intervened and control groups was in the form of decreasing wound healing that appeared on the 8th day.

The signs of wound healing process that could be seen from the intervened and control groups of the caesarean sectio surgery patients on the 3rd day were redness, swelling and tenderness in the wounded area. Wound healing assessment on the 5th and 8th day to the intervened group showed that inflammation or infection of the surgical wounds had begun to decrease and one of which was no tenderness in the wounded area. However, for the control group that was not given snakehead fish extract they still felt pressed-pain at the wounded area.

According to a study conducted by Parliastina, the extract of snakehead fish did not significantly affect wound healing to the intervened group but it clinically decreased wound healing on the 8th day 
[11]. Meanwhile, the study conducted by Fajri showed that snakehead extract giving during 14 days would bring a significant difference between the intervened and the control groups [12].

One of the factors influencing wound healing was age and protein intake. This study showed that the respondents' productive age was between 20-35 years. The more age increased, the skin would experience a change of barrier function to infection, mechanical protection that would decrease the cardiovascular system, respiration and the immune system [13]. Wound healing process would be bad due to poor nutritional status and it could be 4.8 times worse and possibly had longer stay more than 7 days compared to the healing wound process of those who got good nutrition. Hospitalization duration of postoperative patients getting bad nutritional status was approximately $\geq 7$ days while those whose good nutritional status would be shorter, $<7$ days [14].

There were amino acids within the proteins of snakehead fish which included threonine, methionine, valine, histidine, arginine, isoleucine, lysine, phenylalanine, alanine, aspartic acid, glutamic acid, serine, glycine and leucine [15]. Snakehead fish extract could regulate prostaglandin synthesis in the inflammatory phase of wound healing. Prostaglandin itself was a tissue appearing as a reaction to inflammatory and would increase macrophage cells and phagocytes foreign objects that caused infection [6]. Wound healing would not occur if there was no inflammatory phase while the inflammatory phase would increase the prostaglandin hormone and stimulate pain nerve. If it lasted longer there would be more severe tissue damage [16].

\section{Conclusion}

Snakehead fish extract giving to postoperative caesarean sectio patients has effects to blood leukocytes number and wound healing.

Acknowledments. The author expresses her gratitude the Hibah Penelitian Tesis Pascasarjana Poltekkes Kemenkes Semarang for providing research funding. 


\section{Reference}

[1] Nova Primadina, Acmad Basori And David S Perdanakusuma. : Proses Penyembuhan Luka Ditijau Dari Aspek Mekanisme Seluler Dan Molekuler," Vol. 3, No. 1, Pp. 31-43, 2019.

[2] Hetty Maria Sihotang And Herlina Yulianti. : Faktor-Faktor Yang Mempengaruhi Proses Penyembuhan Luka Post Sectio Caesarea," J. Care, Vol. 6, No. 2, Pp. 175-183, 2018.

[3] Ning Xu Landen, Dongqing Li And Mona Stahle. : Transition From Inflammation To Proliferation : A Critical Step During Wound Healing,” Pp. 3861-3885, 2016.

[4] Dinas Kesehatan. :Survei Demografi Dan Kesehatan Indonesia 2017,” P. 606, 2018.

[5] Oxom, Harry And William R. : Ilmu Kebidanan Patologi Dan Fisiologi Bersalin. Yogyakarta : Yayasan Essentia Medika, 2010.

[6] Riski Agustin, Nurdiana Dewi, And Saka Dewi Rahardja. : Efektivitas Ekstrak Ikan Haruan ( Channa Striata ) Dan Ibuprofen Terhadap Jumlah Sel Neutrofil Pada Proses Penyembuhan Luka Studi In Vivo Pada Mukosa Bukal Tikus ( Rattus Norvegicus ) Wistar," Dentino J. Kedokt. Gigi, Vol. 1, No. 1, Pp. 68-74, 2016.

[7] Noor Hidayah, Septi Marsiningsih, mi Kulsum, Sekolah Tinggi Kesehatan Muhamadiyah. : Pengaruh Jus Jambu Biji Merah Terhadap Kadar Leukosit,” Vol. 9, No. 2, Pp. 168-176, 2018.

[8] Esra Küpeli Akkol, Ipek Peşin Süntar, Demet Yilmazer And Murat Alper. : Assessment Of Wound Healing Activity Of The Aqueous Extracts Of Colutea Cilicica Boiss. Bal. Fruits And Leaves,” Evidence-Based Complement. Altern. Med., Vol. 2011, 2011.

[9] Jumriani. : Perbedaan Kadar Leukosit Pada Ibu Ketuban Pecah Dini Dan Partus Lama Di Rsu Al-Fatah Kota Ambon," Universitas. Hasanuddinanuddin, 2018.

[10] Sikni Retno Karminingtyas, Dian Oktianti, And Nova Hasani Furdiyanti. : Keefektifan Penggunaan Antibiotik Profilaksis Pada Pasien Bedah Sesar (Sectio Caesarea)," Vol. 2, Pp. 22 31, 2018.

[11] Dili Parliastina. : Pengaruh Ekstrak Ikan Gabus (Channa Striata) Terhadap Kadar Albumin Dan Penyembuhan Luka Pada Pasien Post Operasi Laparotomi (Studi Di Rsud Brigjend H. Hasan Basry Kota Kandangan)," Repos. Poltekkes Semarang, Pp. 1-5, 2018.

[12] Umi Nur Fajri. : Penagruh Ekstrak Ikan Gabus (Chana Striata) Terhadap Status Luka Sc Dan Peningkatan Kadar $\mathrm{Hb}$ Pada Ibu Nifas Anemia (Studi Di Rsud Hj. Anna Lasmana Banjarnegara)," Repos. Poltekkes Semarang, 2018.

[13] Erfandi Ekaputra, Evolusi Manajemen Luka. Trans Info Media : Jakarta, 2013.

[14] Susetyowati, Maya Ija, And Akhmad Makhmudi. : Status Gizi Pasien Bedah Mayor Preoperasi Berpengaruh Terhadap Penyembuhan Luka Dan Lama Rawat Inap Pascaoperasi Di Rsup Dr Sardjito Yogyakarta,” Indones. J. Clin. Nutr., Vol. 7, No. 1, Pp. 1-7, 2010.

[15] Nadya Aisyatussoffi And Nurllita Abdulgani. : Pengaruh Pemberian Ekstrak Ikan Gabus (Channa Striata) Pada Struktur Histologi Pankreas Dan Kadar Glukosa Darah Mencit (Mus Musculus) Hiperglikemik," J. Sains Dan Seni Pomits, Vol. 2, No. 1, Pp. 2337-3520, 2013.

[16] Touxin Cao. : Daily Administration Of Ibuprofen Modifies Neuroinflammation Gene Expression, But Not Neuroplasticity Gene Expression In Traumatic Brain Injured Rats," Vol. 9, No. November, Pp. 1-5, 2011. 